\title{
DE RAREZAS Y CHANZAS (I): LA FÁBULA BURLESCA DE APOLO Y LEUCÓTOE POR JUAN MATOS FRAGOSO ${ }^{1}$
}

\author{
Belén Molina Huete \\ Universidad de Málaga
}

Mucho más conocido por su faceta de dramaturgo menor de la escuela calderoniana, el portugués afincado en la corte española Juan Matos Fragoso (Alvito, 1609-Madrid, 1689) ha sido poco estudiado en tanto que autor de poemas. Y ello, a pesar de que fue considerablemente más prolífico en este sentido que gran parte de sus colegas de teatro al alcanzar prácticamente el medio centenar de composiciones en verso y casi todas publicadas. Cierto es también que la mayoría de esta lírica se corresponde con piezas de circunstancias de carácter nuncupatorio o celebrativo de algún acontecimiento cortesano, por lo que la composición que me ocupa atesora el interés de encabezar una tríada de fábulas mitológicas impresas que en su producción 
representan serie temática independiente. Anterior a su Fábula de Eco y Narciso (1655) y a La Atalanta (1662), la Fábula burlesca de Apolo y Leucótoe (1652) se distingue en el tono con que afronta el argumento mítico, declaradamente jocoso como precisa su título $\mathrm{y}$, en consecuencia, emplea el romance en cuartetas frente a las octavas que sirven de metro a las otras dos obras. El poema se editó a modo de suelta (7 hojas) en Madrid con fecha de dedicatoria al regidor de la villa el 6 de octubre de 1652. Nos situamos, pues, en los albores de su etapa dramática (su primera comedia conocida es de 1653-1654), pero en un período muy avanzado de su trayectoria poética, que había iniciado hacia 1639 según nos indica el año de su primer poema datado. ${ }^{2}$

Al margen de la mera mención en algunas de las ocasiones en que se ha listado la obra poética de Matos Fragoso, de la referencia puntual a cargo de José María de Cossío en sus Fábulas mitológicas de España dentro del eximio apartado del grupo de poetas portugueses que escribieron en nuestra lengua afectados de la decadencia del gongorismo, o de las breves palabras con que Ma Cruz García de Enterría en su estudio sobre Sociedad y poesía de cordel en el Barroco la caracterizaba como mezcla sin gracia de culteranismo y conceptismo, no se ha llevado a cabo ningún otro tipo de recordatorio crítico ni editorial de esta obra ${ }^{3}$ que suma, a su particularidad dentro del conjunto lírico del autor, la importancia de tratar un tema mitológico apenas transitado por los poetas áureos. En efecto, y frente a otros pasajes de las Metamorfosis de Ovidio - fuente clásica de la Fábula - , el capítulo de Apolo y Leucótoe escasea en nuestras letras y limita su espacio a las consabidas traducciones ovidianas en prosa o verso

2 Para la biografía de Juan [de] Matos Fragoso - o Fregoso - véase E. L. di Santo, «Noticias sobre la vida de Juan de Matos Fragoso», Segismundo, 27 (1978), pp. 217-231. La bibliografía editada más completa sigue siendo la ofrecida por J. Simón Díaz en su Bibliografía de la literatura hispánica, XIV (Madrid, CSIC, 1984, pp. 405-437) y a él se debe también el mayor esfuerzo en el rescate de su parcela no dramática: cf. J. Simón Díaz, «Textos dispersos de clásicos españoles. VII, Matos Fragoso», Revista de Literatura, XVIII (1960), esp. 147-168 y «Cuatro poemas de Matos Fragoso», Revista de Literatura, XXVIII (1965), pp. 97-161. No he podido consultar la tesis inédita de E. L. di Santo, Vida y obra de Juan Matos Fragoso, poeta y dramaturgo del siglo XVII... defendida en la Universidad Complutense de Madrid, 1979, en la que aparece relación de obras del autor.

Sobre su adscripción a la escuela calderoniana, ya en 1663 el poeta aragonés Baltasar López de Gurrea (conde de Villar) así lo registraba en su «Vexamen que se dio en una academia» al frente del libro Clases poéticas. Divídense en Histórica y Fabulosa, Amorosa, Lírica, Jocosa y Piadosa. En variedad de metros y asuntos (cf. J. Ma de Cossío, Fábulas mitológicas en España, Madrid, Espasa-Calpe, 1952, p. 602). La estimativa actual relega a Matos Fragoso a un protagonismo de segunda fila, en que es reseñable, más que su labor original, su colaboración en dramas de varios ingenios así como sus adaptaciones de argumentos lopescos (cf. M. Á. Valbuena Prat, Historia de la literatura española, II, Barcelona, Gustavo Gili, 1963 [1957], $7^{\mathrm{a}}$ ed., pp. 613-614; J. de Entrambasaguas, Lope de Vega y su tiempo: estudio especial de «El villano en su rincón», Barcelona, Teide, 1961, p. 418).

3 Antes de E. L. di Santo y J. Simón Díaz dieron cuenta de la Fábula: C. A. de la Barrera, Catálogo bibliográfico y biográfico del teatro antiguo español. Desde sus orígenes hasta mediados del siglo XVIII, Madrid, Rivadeneyra, 1860, p. 240; D. García Peres, Catálogo razonado biográfico y bibliográfico de los autores portugueses que escribieron en castellano, Madrid, Imprenta del Colegio Nacional de Sordo-Mudos y de Ciegos, 1890, p. 356. Cf. además J. M de Cossío, Fábulas mitológicas en España, Madrid, Espasa-Calpe, 1952, p. 515; Ma Cruz García de Enterría, Sociedad y poesía de cordel en el Barroco, Madrid, Taurus, 1973, p. 386. 
del XVI o a los manuales mitográficos del período. Para cierta amplificación o uso medianamente creativo del mito hemos de remontarnos a la época medieval, con la versión alegórico-moralizante a cargo de Alfonso X en la Segunda parte de su General Estoria - despaganizándola y aplicándola a los amantes de la sabiduría [Apolo] correspondidos [Leucótoe] o no [Clicie] - o a Juan de Mena, quien utiliza algunos de sus ingredientes e innova en algunos otros aspectos para adornar sin ejemplaridad un amanecer en sus glosas en prosa a La coronación del marqués de Santillana. Durante los siglos XVI y XVII, al menos desde el ámbito del impreso y de la fábula mitológica centrada en el episodio de Leucótoe, sólo contamos con el poema de Matos Fragoso y con la titulada Fábula de Apolo y Leucótoe. En chanza que sin lugar ni año publicó también en tono burlesco un desconocido Gabriel de Herrera. ${ }^{4}$

Como queda dicho, el relato mitológico nos sitúa en las Metamorfosis de Ovidio. ${ }^{5}$ El suceso aparece narrado en el Libro IV dentro de la serie de relatos que divierten a las hijas del rey Minias mientras, ocupadas en sus labores, desisten de participar de las fiestas en honor a Baco, cuya deidad niegan. La primera de las historias es la de Píramo y Tisbe. Le sigue la de Marte, Venus y Vulcano. Y al hilo de Apolo, el que avisa al marido engañado, se cuenta la venganza que Venus pergeñó: que sufriera del mismo amor que ella sintió por Marte. Y así, provoca su enamoramiento de la bella Leucótoe mientras debía sus amores a Clitie. Leucótoe era hija de la bella Eurínome y el rico rey Órcamo. Bajo la forma de la madre, Apolo irrumpe en la sala donde se dedican a sus bordados y, argumentando querer contar un secreto a la doncella, despacha a las sirvientas. Revela entonces su auténtica identidad a Leucótoe, quien temerosa y, por ello aún más hermosa al dios, cede sin palabras a su violencia. Los celos de Clitie la conducen a declarar el suceso a Órcamo, quien condena la condescendencia y el

4 Con perspectiva dramática, el argumento ovidiano fue recogido en dos zarzuelas con título Apolo y Leucótea, una de ellas atribuida a Calderón de la Barca (cf. V. García de la Huerta, Theatro Hespañol, Imprenta Real, Madrid, 1785, p. 25) y otra debida a don Pedro Scoti de Agoiz con música de Juan Hidalgo estrenada en Madrid el 22 de diciembre de 1684 con ocasión de celebrar el cumpleaños de la reina (cf. L. Fernández de Moratín, Catálogo de piezas dramáticas publicadas en España desde el principio del siglo XVIII hasta la época presente [1825], en Obras de don Nicolás y don Leandro Fernández de Moratín, Madrid, La Publicidad-Rivadeneyra, 1850, $3^{\mathrm{a}}$ ed., p. 327). En ambos casos, la posible confusión con Leucótea, divinidad del mar, queda aclarada por la implicación de Apolo, ausente en los relatos relacionados con ella. También en Italia contamos con un precedente musicado del mito, representado en el teatro Grimano de Venecia, a cargo de A. Aureli, Gl' amori d'Apollo e di Leucotoe: Dramma per Musica, Venecia, Nicolini Francesco, 1663. Otra muestra italiana, que no he podido consultar, es G. Capponi, Leucotoe idillio dell'Animoso Accademico Seluaggio. All'illustrissimo, e reuerendissimo Bonifazio cardinale Caetano ... Venecia, Gio. Battista Pulciani, 1609.

El poema de Gabriel de Herrera es también una edición en suelto, sin lugar ni año, con único ejemplar conocido sito en la Hispanic Society of America. Su estudio y edición anotada ocupa la segunda entrega de este artículo.

5 El origen de la historia parece remontar a uno de los textos perdidos de Hesíodo (s. VIII-VII a. C.). Es fuente dudosa, pero es Lactancio, imitador de Ovidio del s. VI, en sus Narrationes IV, 5 quien remite al autor griego (cf. A. Ruiz de Elvira, Mitología clásica, Madrid, Gredos, 1984, p. 450). 
deshonor de su hija enterrándola viva pese a sus súplicas invocando a Apolo como responsable del abuso frente a su voluntad. Nada pudieron por rescatarla los esfuerzos del arrogante Febo que, lleno de dolor, quiso devolver a la vida a la inerte joven con el calor de sus rayos. Viendo que el destino le negaba dicha posibilidad, esparció un oloroso néctar que impregnó la tierra e hizo brotar el árbol del incienso; se cumplía así el deseo del frustrado enamorado de que de ese modo podría elevarse y llegar al cielo. Abandonó entonces Apolo a Clitie, que se sumergió en un mar de celos y de inanición (nueve días en ayuno y sin más agua que sus propias lágrimas), sin más oficio que el de seguir al dios en su recorrido celeste. Su fin fue la metamorfosis en heliotropo de pálidas hojas, aún enamorada y perseguidora del rostro de luz. Las hermanas se admiran ante relato semejante, al que apenas dan crédito si no fuera porque todo lo pueden los dioses verdaderos.

Sustanciando lo que con detalle queda reflejado en las «Notas y comentarios» que acompañan a mi edición, podríamos distinguir las siguientes operaciones sobre la materia prima ovidiana que definen la naturaleza de esta Fábula de Apolo y Leucótoe de Matos Fragoso:

a. La reducción del mito a la faceta de la conquista y la consecución de la doncella obviando el interés propio de una fábula ovidiana como es el de la metamorfosis final, amputando toda la historia de Clitie e incluso alterando la secuencia original adelantando el descubrimiento de Apolo para conseguir un efecto de focalización más intenso. En este sentido, el primer estadio burlesco se efectúa frente a una imitatio ortodoxa y se orienta hacia el efectismo jovial de lo erótico que descubre en la entrega voluntaria de Leucótoe (forzada en Ovidio) la metamorfosis primera de una virgen («la transformación más nueva»).

b. La amplificación habitual en traducciones, exégesis y otras praxis del modelo ovidiano se ensaya aquí únicamente en dos momentos tópicos: la descripción de Leucótoe y el parlamento de Apolo para atraer el favor de la joven. La descriptio puellae, que conserva la secuencia lineal del retrato con desproporción en número de estrofas pero con mecanismos de compensación por concentración de recursos, mantiene vigente la ecuación platónica de lo externo = interno, pero evidentemente, en virtud del código paródico que condiciona todo el texto, Leucótoe no es la cándida donna angelicata sino que trasluce en su hermosura el halo de la pasión y el ardor amoroso. Desde la esfera ahora de la sermocinatio, el discurso apolíneo parodia el canto polifémico con un 
variado despliegue de evocaciones mitológicas que dan valor de deidad a su figura al tiempo que dilogías y erotemas lo perfilan como rico y satisfactorio amante.

Afirma el poema un estilo acusadamente gongorino que le otorga cierto acento ampuloso, «vicio» que reconocieron a Matos Fragoso sus propios contemporáneos. ${ }^{6}$ Sin grandes hallazgos poéticos, desfilan entre los versos cultismos léxicos, hipérbatos, fórmulas sintácticas estilísticas, alusiones mitológicas o eruditas, perífrasis alusivas, contraposiciones y bimembraciones, paralelismos... casi un calco aplicativo de la lengua poética de Góngora que diseccionó Dámaso Alonso. Tales recursos, empero, son empleados con menos profusión que en sus otras dos fábulas mitológicas, donde el apego al cultismo gongorino alcanza cotas extremas. Pero son esencia los elementos en pro de la agudeza y el desarrollo de lo cómico los que marcan el rumbo de la Fábula: dilogías, juegos de palabras, locuciones coloquiales o populares, imágenes parodiadas, anacronismos... Todos ellos encaminados, conjuntamente con las recreaciones sobre la inventio primitiva y su disposición estratégica en el texto en gradación ascendente, a burlar las expectativas del lector, provocar su sorpresa y su sonrisa. Con una perspectiva más celebrativa (erótico-festiva) que censora, la narración ovidiana quedaba actualizada a partir de su transformación en un mensaje que dejaba al descubierto la imagen de la mujer cortesana, codiciosa y ambiciosa cuyos melindres ceden pronto ante el deslumbramiento de las ofertas materiales (poder, riqueza, posición y exposición) y sexuales de un gran caballero seductor.

En Ovidio, tan propenso él mismo a humanizar y poner en chanza a los dioses, esta fábula resulta realmente trágica. La inversión se hace, pues, definitiva en Matos y su romance se nos revela inmerso en una innovadora imitación que podríamos encauzar en dos direcciones con vértice de encuentro. Una primera, la que tiene su referente en la transformación hacia las lindes burlescas que sufre el género de la fábula mitológica desde el poderoso magisterio gongorino y el quehacer de autores menores pero de prolija actividad en este tipo de textos durante la primera mitad del XVII, como Anastasio Pantaleón de Ribera (1600-1629); para ellos se trata de recrear lo conocido en una forma de escritura que se encuadra dentro de lo lúdico, del ejercicio poético barroco donde el lenguaje y su propio refactum genérico constituye la diversión, el placer estético, la comicidad. Y una segunda, cuyo encuadre se define en las coordenadas de intersección entre literatura y público, cuando el humor ligado a la sátira social se vehicula a través un producto literario de «divulgación» en el más

6 Cf. los versos que Jerónimo de Cáncer (1649) pone en boca del autor: «Con las aguas que llueven / desde el Parnaso / las voces castellanas / se me han hinchado» (J. C. González Maya, «Vejamen de D. Jerónimo Cáncer. Estudio, edición crítica y notas», Criticón, 96 (2006), 87-114, p. 107. 
amplio sentido de la palabra. «Arrímense ya las veras / y celébrense las burlas», había dicho felizmente Góngora.

En este espacio híbrido de subversión genérica entre las burlas y las veras, ${ }^{7}$ la Fábula burlesca de Apolo y Leucótoe de Juan Matos Fragoso no deja de ser uno de esos juguetes literarios en los que al margen de su escasa calidad lírica es posible reconocer la vigencia de un género como el de la fábula mitológica, en un grado concreto de vitalidad en consonancia con las constantes literarias y sociales del momento en que nace. En nuestro caso, parodia, admiratio, festejo y sátira confirman un apurado encuadre barroco.

Creo no pecar si en ese mar de composiciones mal llamadas poéticas sólo por estar en verso y ser vagamente ingeniosas, distingo esta Fábula por su singularidad múltiple: única obra en este tono de las escasas mitológicas ensayadas por el autor; única prácticamente en su modalidad en verso castellano de este controvertido mito tratado como fábula en la literatura áurea española; especial en el tratamiento paradigmático de la composición, huyendo de la esencia de la metamorfosis ovidiana para recrearse o fijarse en la metamorfosis natural que le precede en aras de evidenciar su objetivo burlesco. En este sentido, de algún modo, denota una intención de escape a la involución a la que llega el género. Y, frente a otras composiciones con las que podría quedar alineada, también en este sentido se evade sin duda de la acusación de quedar limitada en el «aderezo poético» olvidando la novedad de lo narrado. Ciertamente su desarrollo formal en la línea cultista no va más allá de la parodia de momentos tópicos en el discurso petrarquista o clásico y de pocos ingeniosos chistes o juegos de palabras sobre los que la ironía erótica planea torpemente solapada. Sí declara una estructura bien medida, con goznes internos que articulan sus diferentes grados de intensidad, si bien no en cotas como las que podemos hallar en el maestro Góngora. Consciente de un lector poco exigente en el deleite estético pero presto a la risa fácil y al divertimento, la obra parece romper al menos en un punto - superando el lastre de la exuberancia barroca y la frondosidad de ingenio - el pecado de trivialidad que marcaba según E. M. Wilson este tipo de composiciones. ${ }^{8}$

Acaso por las razones enunciadas o acaso por el mero hecho de constituir una rareza bibliográfica (ejemplar único conocido en la BNE VE/156-40) considero justificada la recuperación de esta Fábula burlesca de Apolo y Leucótoe. De manera general en su edición, he modernizado las grafías y regularizado la ortografía y la puntuación

7 Véase para su contextualización, A. Pérez Lasheras, «Fustigat mores». Hacia el concepto de la sátira en el siglo XVII, Zaragoza, Universidad, 1994, pp. 161ss.

8 E. M. Wilson, «La estética de don García de Salcedo Coronel y la poesía española del s. XVII», Revista de Filología Española, XLIV (1961), p. 25, apud. Ma C. García de Enterría, op. cit., p. 161. 
conforme a la norma actual, conservando aquellas formas que aun en desuso hoy son admitidas (invidia, escura; otubre, emienda, acetas, respecta; propria). Advierto, sin embargo, que he acomodado a su realización presente términos como obstenta y essempta, no recogidos en los diccionarios académicos, aun cuando puedan connotar voluntad de afectación y su uso se documente en escritos contemporáneos. Asimismo, he mantenido las contracciones destos, dellos, esotra y la disyuntiva $u$ ante $d$, empleada en el siglo XVII según Autoridades para evitar la malsonancia. Hago especial recordatorio de la actualización de los nombres propios Ossa en Osa y Fitón en Pitón, así como la opción por las formas esdrújulas de Leucótoe, Órcamo y Eurímone que acomodan bien a la medida y al número del verso en todo caso. Las adiciones significativas al texto van indicadas entre corchetes, y he marcado la diéresis en los versos pertinentes. De manera puntual, las notas recogen las licencias e incidencias que he considerado relevantes en relación con mi traslado. Desde el punto de vista tipográfico, quedan ausentes los adornos e ilustraciones que acompañan al poema (la cruz griega que inicia la portada, el friso que encabeza la dedicatoria y el exuberante adorno de tinte indigenista al cierre). Reúno en mi presentación la portada y la dedicatoria y recompongo las líneas de la primera, que en el original rezan: «FABVLA / BURLESCA / DE / Apolo, y Leucotoe. / Dedicada / A Don Gabriel de Rojas, Caua- / llero del Orden de Santiago, y / Regidor desta Coronada Villa de Madrid. / POR / Don Iuan de Matos Fregoso».

Por último, las «Notas y comentarios» no son más que un modesto intento de resaltar los mecanismos retóricos que sustentan el poema a fin de superar siquiera mínimamente las caracterizaciones generalizadoras que sobre él se han vertido y plantear un punto de partida para establecer el diálogo con otros textos, en especial con su afín Fábula de Apolo y Leucótoe. En chanza de Gabriel de Herrera. Pero es obra que desea - y yo concedo- nueva ocasión. 


\title{
FÁBULA BURLESCA DE APOLO Y LEUCÓTOE
}

\author{
DEDICADA A DON GABRIEL DE ROJAS, \\ CABALLERO DEL ORDEN DE SANTIAGO Y \\ REGIDOR DESTA CORONADA VILLA DE MADRID \\ POR \\ don Juan de Matos Fregoso
}

\begin{abstract}
Luego que me dio en los ojos la luz de sus armas de v. m., reconocí en la elección de buscarle mecenas feliz estrella; pues las que goza su generoso escudo parece que están prometiendo benigno influjo a cuantos solicitan su patrocinio. Y aunque el don que ofrezco sea corto, por eso le crece mi afecto, y su valor, que sólo se satisface destos breves indicios de la voluntad. Pero qué mucho si todas estas partes gloriosas ha heredado v. m. con la ilustre sangre de aquel varón esclarecido Sancho Ruiz, primogénito de la Casa de Rojas, ricohome del Rey don Alonso el Sexto de Castilla y León, que ganó a Toledo, que casó con María Díaz Duque, cuyo rebisnieto fue Ruy Díaz de Rojas, ilustre tronco suyo que ha producido frondosos ramos de singulares varones en letras y armas que han ennoblecido a estos reinos, de que están llenas las Crónicas y Nobiliarios de España, siendo v. m. uno dellos por quien se adelantan sus esplendores, no solamente en Castilla sino también en el imperio del Nuevo Mundo. Dios guarde a v. m. con las felicidades que merece. Madrid, a 6 de otubre de 1652.
\end{abstract}

El más afecto que S[u]. M[ano]. B[esa].

Don Juan de Matos Fregoso 


\section{FÁBULA BURLESCA \\ DE APOLO Y LEUCÓTOE}

5

10

15

20

25

30

35

40

De aquella, a quien por sus muros

eterna fama celebra,

ciudad que el Éufrates baña

y toda el Asia respecta;

donde de umbrosos pensiles

máquina fragante ostenta

laberintos que compuso

la que fue de Oriente reina;

de Babilonia, en efecto,

era, según justa herencia,

rey Órcamo, y Leucótoe

infanta por línea recta.

Ésta, pues, incendio hermoso,

nació para ser afrenta

de las deidades en cuanto

dilatado el Ganges riega.

Su proceloso de rizos

golfo en esparcidas trenzas,

ni de Ofir mazorca rica

ni vaga de luz madeja

se admiró (bien que segura

pudiera cualquier melena,

a otra como el sol dorado,

reputarla de bermeja);

invidia, sí, al más bruñido

azabache, en cuyas hebras

un mar negro se fingía

de atezadas ondas crespas.

Con su frente eran mulatas las alburas más flamencas, plateado borrón la luna y lunares las estrellas.

No tantos rindió despojos Cupidillo a la ballesta en atractivos bodoques o acrisoladas saetas,

cuantos la ninfa a Cupido, la vez que altiva dio muestras de desdén flechando ceños en un zaino arquear de cejas.

Bellos luceros de Angola sus ojos, radiante emienda fueron del más claro signo, 
del más brillador planeta,

$$
\text { a cuyo ardor las pestañas }
$$

dulce anhelaban violencia,

pues con gitanos ensayos

gala hicieron de ser negras.

De accidentes del catarro

libre la nariz y exenta,

tuvo siempre sin ser roma

mil gracias e indulgencias.

Con sus purpúreas mejillas

55

son, a pesar de Venecia,

vergüenza las escarlatas,

la cochinilla una puerca.

Cual su estrecha indiana boca

no cuajó en rocas marpesias

Trinacria finos corales

60

ni Ormuz las preciosas perlas;

sin agraviar a ninguna,

dejar pudo, en mi conciencia,

desmentida por la barba

la hermosura más febea.

Columna de nieve al torno, en quien todo un cielo asienta, era al mármol de Caristos su cuello deshonra tersa.

Lo que licenció el corpiño,

lo que bochorno dispensa, todo fue Sierra Nevada, nada fue Sierra Morena.

Más matante que un barbero (sin bacías ni ballenas)

era el talle, tan buïdo que le empuñara cualquiera.

Con sus manos los jazmines se arriman y la azucena, por todos diez mandamientos su poco candor confiesa.

$\mathrm{U}[\mathrm{r}]$ na espaciosa al pie breve hizo pulida defensa a un coturno de polvillo, un zapato tabaquera.

A ésta en fin (que ninfa hermosa, sin desmentirse de honesta, pudiera prestar desgarro a la venus más soltera), rendido Apolo, a pesar de divinas resistencias, 
vengativa cual por Dafne

sintió la dorada flecha.

Prevenido arpón castigo

fue de acusación venérea

con que el chiprïota ciego

aplazó maternas quejas.

Tocado el agíleo dios

de ardiente estímulo apenas, casta virgen solicita,

Aurora sigue más bella,

cuando, de Órcamo al cuidado,

que inmatura novia cela,

probó sus ansias frustradas

desvanecidas sus tretas.

Viendo, pues, a la amorosa

cuanto difícil empresa

cerrado el paso - que entonces

aún no se usaban las dueñas-,

$\mathrm{y}$ viendo que en vano, herido

de nocivo rayo, apela

a su ser contra el enojo

de ofendida Citerea,

cauto, de Eurímona imita

la forma $y$, fingida reina,

se fue al cuarto donde estaba

la susodicha princesa.

Y allí, despidiendo a cuantas

la acompañaban doncellas,

para ciego intento, sabio

terció la doble a una puerta.

Atenta al medroso indicio

la infanta que no recela

incasto peligro donde

falsa majestad venera,

humilde se expuso cuando

el leucadio amante deja

de femeniles adornos

la ya prolija cautela.

$\mathrm{Y}$ antes que el susto pudiese

dar tiempo a contrarias quejas, desta suerte habló, expresando en cada acento una pena.

«Hijo del cretense Elicio soy, de aquel a cuya diestra

yace sobre Olimpo y Osa

la altiva ambición deshecha;

el que a despecho de Juno 
venció la Pitón soberbia

que causó a mi madre tantas

desesperadas molestias;

el fugitivo homicida

que de Tesalia en las selvas

regí a un balear crujido

mil obedientes vitelas;

el que de Ticio mi hermano

puse las entrañas fieras

al ave voraz, segundo

castigo de su torpeza;

el que al padre de Coronis,

loco y sacrílego Flegias,

sujeté en el orco donde

gime sobre estable peña;

el que al arrogante frigio

155

la piel desnudé sangrienta

cuando entonando conmigo

cisne cantó sus exequias;

$y$, en fin, el que al mundo todo,

si se me pone en la fuerza,

castigaré con modorras,

abrasaré con jaquecas.

Éste soy, pero el amor, que tantos dioses sujeta, hoy a tu beldad me rinde y por tus ojos me eleva.

A ofrecerte vengo humilde fe que, si propicia acetas, señora serás de cuanto mi fuego imperante engendra.

De todo el luciente globo estas nocturnas centellas haré que a tus plantas sirvan de rodapiés o carpeta.

$\mathrm{Y}$ hasta mi triforme hermana, hasta mi sabia partera,

dejaré a escuras por darte la luz que mi luz le presta.

Cuanto Fenicia y Pancaya, cuanto Licia, Arabia y Tebas en sacrificios y aromas sobre sus aras me feudan;

y cuanto en llanto destilan a las que hoy álamos besa Erídano el tronco duro, Héliadas de su ribera, 
185

190

195 será tuyo si me libras

desta amorosa dolencia; haré entre sacras deidades jurarte deidad suprema.

El ave que escarmentada busca las corrientes frescas, donde en acordes falsetes la muerte se lisonjea;

y esotra que de sí propria descendiente, en la desierta Arabia, entre nardo y mirra, con su sangre se lardea;

y hasta la que de Argos goza bella impresión, lumbre ciega, por cuya pompa es trofeo de Juno al tirante puesta; todas, si todas te agradan, perdigadas o rellenas, pasto serán de tu gula sobre mi opulenta mesa.

Aprovecha tu hermosura, mis cuidados aprovecha, triunfa de un dios por amante, logra imposibles finezas.

Tendrás, si dueño me eliges hoy de tus virgíneas prendas, los más profundos diamantes que pule acerada rueda.

Sobre mi luciente coche será en rutilante esfera la vía Láctea tu calle Mayor y tus covachuelas».

Dijo; y la ninfa, obligada a tan divinas promesas, dio para nupcial ensayo sus permisivas licencias.

Apolo entonces cogiola de una mano, u de una pierna, y al tálamo fue logrando la transformación más nueva. 


\section{NOTAS Y COMENTARIOS}

\section{Dedicatoria}

Gabriel de Rojas. Trátase de Gabriel de Rojas Virués, natural de la villa de Madrid, de la que ocupó el cargo de regidor. Había ingresado en la Orden de Santiago el 19 de septiembre de 1650. Véase A. y A. García Carrafa, Enciclopedia heráldica y genealógica Hispano-americana, Madrid, Antonio Marzo, 19191963, s. v. Rojas.

su generoso escudo. El escudo de armas de la rama originaria de los Rojas presentaba cinco estrellas de azur en sotuer sobre campo de oro. Es recurrente la cita a su exaltación por Luis Zapata en el Carlo famoso (Valencia, Ioan Mey, 1566, canto XXIV, f. 140): «Cinco estrellas azules esculpidas / en ese escudo de oro reluciente / son de los Rojas armas conocidas...».

Pero qué mucho... Interpreto el sentido del largo período sintáctico que aquí se inicia para justificar mi puntuación: 'Pero cómo considerar en mucho la herencia noble de todos sus antepasados si V. M. los aventaja al haber ampliado la magnitud de su fama extendiéndola a América'.

La familia Rojas, en efecto, reza entre las más antiguas y nobles de Castilla. Frente a otras propuestas, como la de Luis Salazar y Castro en su Historia genealógica de la Casa de Lara (Madrid, Imprenta Real, 1696-1697), Matos sigue aquí la línea dibujada por Alonso López de Haro en su Nobiliario genealógico de los reyes y títulos de España (Madrid, Luis Sánchez, 1622): Sancho Ruiz Rojas, segundo señor del solar de Rojas, destacó durante el reinado de Alfonso VI (hacia 1090); casó ciertamente con doña María Díaz Duque y de su matrimonio nació Diego de Rojas, tercer señor de Rojas, privado y mayordomo de Alfonso VII. Le sucedió su hijo Ruy Díaz de Rojas, servidor de Sancho III, Alfonso VIII y Fernando III el Santo, con quien colaboró en conquistas andaluzas. Le acompañó en ellas su descendiente, Sancho Ruiz de Rojas, el que sería quinto señor de Rojas y padre del Ruy Díaz de Rojas que como «rebisnieto» queda mencionado en esta dedicatoria.

La conexión con el Nuevo Mundo va ligada especialmente a México. El padre de don Gabriel, el madrileño Francisco de Rojas, fue Oidor de su Real Audiencia, y el propio regidor casó con la mejicana de origen segoviano doña María Mejía de Sandoval y Marquedo. El hijo de ambos, Juan de Rojas Mejía, nació asimismo en el país ultramarino (vid. A. y A. García Carrafa, op. cit.).

\section{TEXTO}

1-8. La perífrasis inicial que sitúa la acción en Babilonia alberga la referencia a sus afamados jardines colgantes, cuyo encargo atribuye la tradición a Semíramis, reina de Nínive. Cf. s. v. pensil, el Diccionario de Autoridades [1726-1739], Real Academia Española, ed. facs., Madrid, Gredos, 1990 (en adelante Aut.). La imagen de Babilonia como ciudad exótica, plena en belleza y esplendor, convive a su vez con la concepción bíblica, que la ideaba como ciudad aliada del pecado: lujos desenfrenados, prostitución, usura... (véase Apocalipsis 18,1-8). Este pasaje resulta más preciso que en Ovidio, quien vagamente ambienta con alusiones orientales y persas. Nótese que durante el Siglo de Oro, reuniendo prosperidad y corrupción, ciudades como Madrid o Sevilla tomaron el apelativo de Babilonia (cf. las notas a los vv. 215-216).

11-12. Al tratar de Órcamo, regente de las ciudades aquemenias (Persia), Ovidio le reconoce haber sido «séptimo en la línea que viene del antiguo Belo» (Metamorfosis IV, 212-213). Fue Belo, según S. de Covarrubias en su Tesoro de la lengua castellana o española [1611], hijo de Nembroth, segundo rey de Babilonia adorado como dios. Ruiz de Elvira llama la atención sobre los orígenes puramente griegos de este rey Belo sin que quede explicada su asimilación con una figura oriental de carácter semidivino (Ovidio, Metamorfosis, ed. de A. Ruiz de Elvira, Madrid, CSIC, 1990, p. 226). El apunte genealógico sobre el padre de Leucótoe parece lugar común en los recordatorios del mito ovidiano: Alfonso X lo reproduce en la Segunda parte de su General Estoria (cap. LXXVIII, 153c) y Juan de Mena lo amplía detalladamente en la glosa en prosa a la copla XXV de La coronación del marqués de Santillana: «El qual Órcamo deçendía, segund la cuenta de los estoriales, del linaje del rey Júpiter por esta manera: Júpiter de la reina Ío engendró a Épapho, y Épapho a Belo, e Belo a Danao y Egipto e Abante, e Abante a Acrisio e Agenor, e Acrisio a Danae, Danae a Perseo, Perseo a Achimenides, Achimenides a este Órcamo de quien fablamos». La Fábula de Europa de Anastasio Pantaleón de Ribera utiliza también la misma 
expresión para aludir a Europa (v. 45-47): «Hija del rey de Fenicia, / Agénor [hermano de Belo], cuya corona / heredó por línea recta» (A. Pantaleón de Ribera, Obra selecta, ed. de J. Ponce Cárdenas, Málaga, Universidad, 2003, p. 76).

13-16. Cabría interpretar la metáfora incendio hermoso con que se introduce la belleza de la princesa como relativo ejercicio de prolepsis, teniendo en cuenta su calificación de bermeja en los versos que siguen y la metamorfosis final de Leucótoe en incienso que, además, queda omitida en esta versión de la fábula. Pero parece oportuno acudir al sentido figurado de incendio («cualquier cosa que origina gran calor» o «en el sentido moral [...] aquellos afectos que acaloran y encienden el ánimo: como el amor, la ira, etc.», Aut.), que avanza desde el principio el carácter ardiente que la muchacha adopta en el texto de Matos, y que es por otra parte tópico en las mujeres babilónicas. La belleza de Leucótoe queda exaltada desde Ovidio como hermosura que supera a la de su propia madre, «la más hermosa mujer del país de los aromas, Eurínome; pero cuando creció la hija, tanto como la madre superaba a todas las demás, superaba a la madre la hija» (Metamorfosis, IV, 208-211). Resulta impreciso ese "país de los aromas» de donde fue originaria Eurínome, aunque se especula con Arabia o Siria (Ovidio, ed. cit., p. 131). El autor obvia aquí esa mención a la herencia materna para extender la suprema belleza de Leucótoe a los territorios próximos más allá de las fronteras persas del Este: los bañados por el Ganges, río sagrado por excelencia y extensísimo en su cauce al atravesar toda la India. La conformación de una antítesis alusiva con base en los elementos 'fuego'-'agua', permite así un mayor efecto sobre la hipérbole tradicional.

17-28. Ausente en Ovidio - que tan sólo pondera la hermosura de Leucótoe en relación con su madre - , comienza aquí, y se extiende hasta el v. 84, un pormenorizado retrato de la muchacha, parodia de la descripción petrarquista al uso; el dibujo de su oriental belleza exterior conlleva paralelamente su etopeya de dama juguetona con lo licencioso y las artes de seducción. El texto original reza: «Su proceloso de riços / golfo, en esparcidas trenças, / ni de Ofir maçorca rica, / ni vaga de luz madexa. / Se admirò (bien que segura / pudiera qualquier melena, / a otra como el Sol dorado, / reputarla de bermeja.) / Inuidia si al más bruñido / azabache, en cuyas hebras / vn mar negro se fingia, / de ateçadas ondas crespas». Existe cierta dificultad en la reconstrucción sintáctica de este pasaje que, sin embargo, no parece impedir encaminar su sentido acudiendo a la consideración de expresiones zeugmáticas y a la suplencia de términos en elipsis. Mi propuesta es la siguiente: 'el abundante y desordenado (golfo proceloso) cabello rizado de Leucótoe producto de deshechas trenzas (en esparcidas trenzas) no tenía en consideración (se admiró) ni el rubio intenso (ni de mazorca rica [de] Ofir) ni el rubio claro (ni [de] madeja vaga de luz), bien que segura pudiera cualquier melena al confrontarla con otra melena realmente dorada (a otra como el sol dorado [comparada]) reputarla de bermeja, por lo encendida y ardiente'. Su inclinación es a lo oscuro (invidia sí al más bruñido azabache, del árabe "piedra negra», Aut.) y, retomando la imagen marina primera [en cuyas...], sus hebras se identifican con un intenso negro mar encrespado'.

El fragmento acusa, además de las retóricas omisiones indicadas: el empleo recurrente del hipérbaton combinándolo con construcciones paralelísticas y quiasmáticas (vv. 19-20); la presencia del cultismo léxico proceloso («lo que frecuentemente padece tempestades y tormentas», Aut.) adornado con un uso metafórico y poético del término golfo ('confusión', 'abundancia y multitud', Aut.); extensiones semánticas como las de mazorca y madeja, ambas 'hilo devanado' (Aut.), ya fijadas en el concepto 'mata de pelo'; referencias eruditas como Ofir, territorio oriental al sur de Arabia reconocido por su riqueza en oro, de donde Salomón mandó traer más de una tonelada del metal precioso para la construcción de su templo (cf. Reyes I, 9, 26-28 o Job 22, 24); intensificaciones marcadas por la reiteración de términos equivalentes en su significado, ya próximas, ya en posiciones de inicio y cierre de la secuencia descriptiva (vv. 17-18 / 26 / 27-28); efectivos contrastes que realzan los dos aspectos destacados de la muchacha (nótese la gradación no rubio-aunque bermejo/ardiente-moreno, con nexo en el término bruñido); y acaso el empleo como mecanismo humorístico de lo que G. Garrote («"Maestro/virtuoso, libertino, zurdo, diestro»: la erótica heterodoxia de Samaniego"», en E. Palacios Fernández [coord.], Félix María de Samaniego y la literatura de la ilustración, Madrid, Biblioteca Nueva, 2002, pp. 111-112) ha denominado «falsa segmentación morfológica» aplicado a reputarla, para evocar jocosamente la doble cara de la muchacha y encauzar la dilogía en torno a bermeja que culmina la artificiosidad. En efecto, Leucótoe no es la dama rubia del canon oficial, sin embargo, puede ser considerada 'bermeja' en contraste con una de ellas. Si la princesa es morena voluptuosa tal como se explicita - en la línea de la simbología tradicional que arranca del propio Cantar de los cantares - , el color bermejo - equivalente en ocasiones a un rubio muy vivo - implicaría un aumento en el grado de color e intensidad, lo cual justificaría su aplicación. Ya Covarrubias en su Tesoro marcaba los particulares de esta tonalidad: «Entre rojo y bermejo hacemos diferencia, porque el rojo es una color dorada: la bermeja es más encen- 


\section{Belén Molina Huete}

dida, y arguye más calor...». La evocación al incendio hermoso de unos versos atrás se hace evidente, sobre todo si avanzamos en la definición: «y así son tenidos los bermejos por cautelosos y astutos», poseedores de una «agudeza maliciosa extraordinaria y perjudicial». Devendría aquí, pues, también aplicado a Leucótoe en su faceta de mujer tentadora y concupiscente, el sentido despreciativo que adquiere el término bermejo en nuestra tradición lírica áurea y que todos reconocemos en el famoso soneto de Quevedo «Bermejazo platero de las cumbres» asociado a Apolo y a un contexto de asedio sexual. Véase F. González Ollé, «Fisiognómica del color rojizo en la literatura española del Siglo de Oro», Revista de Literatura, XLIII, 1981, pp. 153-163. El v. 31 precisa sinéresis en plateado.

29-32. Lo moreno de su pelo contrasta con la blancura extrema de su frente, evidenciada en la serie de hipérboles de este grupo de versos que hacen oscuras (mulatas, plateado borrón, lunares) las realidades más luminosas: las estrellas, la luna y las alburas más flamencas, refiriendo las mujeres oriundas de Flandes, famosas por su excesiva blancura (según Covarrubias, los nativos de Flandes «son muy dispuestos, gentiles hombres, blancos y rubios, y también las mujeres»). Al juego contrastivo blanco-negro se suma tímidamente el efecto paronímico de luna-lunares. Nótese igualmente el carácter transitivo del término mulatas entre el negro de la cuarteta precedente y su alternancia en ésta con el blanco.

33-40. Continúa el retrato en secuencia sucesiva y tras cabello y frente siguen las cejas. Su semejanza en forma con el arco provoca la oportunidad de equiparar su poder fulminante con el del propio Cupido e incluso de superarlo (adviértase en este sentido el empleo del diminutivo Cupidillo en la primera parte de la enunciación focalizada en las facultades del dios y del positivo Cupido en la segunda, al tratar del poderío de la dama). Quedan aquí combinadas, pues, la tradición trovadoresca expresiva de las armas tradicionales con que Amor iba prendiendo de amor a las criaturas - arco y ballesta con flechas y bodoques -, y la tradición petrarquista expresiva de las heridas, consumada aquí por Leucótoe en nuevo ejercicio de superioridad. El retrato se adentra así nuevamente en lo íntimo del personaje destacando su faceta más tendenciosa. Al carácter zaino ('falso, intencionado', también 'oscuro, negro') del gesto de sus miradas se suma el ser denominada ninfa, término apropiado para vincular con Cupido pero irremediablemente denotador de meretriz en su acepción germanesca: «prostituta tributaria de un rufián» (J. L. Alonso Hernández, Léxico del marginalismo del Siglo de Oro, Salamanca, Universidad, 1977). Puede considerarse especialmente gongorina la fórmula consecutiva que enlaza la serie (no tantos...cuantos) así como la identificación que sustenta la imagen desarrollada, puesto que cejas = arcos aparecía ya en la Fábula de Hero y Leandro «Aunque entiendo poco griego...» (v. 118) y en la de Píramo y Tisbe "La ciudad de Babilonia..." (v. 51); véase J. Ponce Cárdenas, Góngora y la poesía culta del siglo XVII, Madrid, Laberinto, 2001, p. 148. El verso precisa sinéresis en arquear.

41-48. El atopismo burlesco de Angola, para caracterizar la negrura de los ojos de Leucótoe se combina aquí con la alusión más popular a los gitanos ensayos de sus pestañas. Así, al referente oscuro de la tez de los gitanos se suma igualmente su fama de raza «engañadora, embustidora» (Covarrubias), si bien por extensión se llama también gitano «el que tiene atractivo en lo que dice y habla, aunque no sea para engañar; y así se dice es muy gitana por ser muy halagüeña y cariñosa» (Aut.). El desdén de las cejas queda, pues, compensando por las concesiones de los ojos y las pestañas. En lenguaje germanesco ser negro, como las pestañas de la princesa, significa ser «astuto y taimado» (Aut.). Tal vez en ese sentido sería conveniente entender la hipérbasis del v. 46: anhelaban dulce violencia. Por otra parte, la exaltación de radiantes ojos negros (aquí en paralela ponderación astronómica) cuya oscuridad no evita su esplendor había quedado ya plasmada en la Hero gongorina y también en la Europa de su seguidor A. Pantaleón de Ribera: «Dos estrellas de Guinea, / diócesis de Etiopía, / alumbraron en sus ojos / a pesar de negras sombras», vv. 61-64, (A. Pantaleón de Ribera, op. cit., p. 76).

49-52. Gira este momento del retrato destinado a la nariz en torno a la antanaclasis sobre roma: 'nariz chata' y 'ciudad'. La definición que para catarro ofrece Covarrubias - «la destilación que cae de la cabeza a la garganta y al pecho [...]. Lo mismo significa romadizo...»- explica que la nariz de Leucótoe esté desprovista de los accidentes del catarro (flujos, mucosidades) pero a la vez justifica el que se insista en que no es roma. Tener nariz roma, al margen de su vinculación con la sífilis, era generalmente indicativo de fealdad. Además de salvarla de esta acepción negativa en su aspecto exterior, la alusión a la sacra Roma incide otra vez en la falta de santidad de la muchacha (sin ser roma), que tuvo mil gracias e indulgencias no tanto eclesiales sino mundanas: «facilidad en perdonar, disimular culpas o en conceder gracias [...]. Vale también demasiada benignidad, permisión o disimulación con alguno que le ocasiona libertad en el obrar o falta de temor » (Aut.). El v. 52 exige dialefa en $e$ indulgencias, lo cual parece marcar la tilde grave que en el original acompaña a la conjunción è.

53-56. Sin dejar caer la alusión erudita a Venecia como símbolo del lujo real del color púrpura (Tiro lo era del producto en sí), el destacado rojo de las mejillas de Leucótoe se plasma en una comparación 
zeugmática ('[comparadas] con sus purpúreas mejillas') degradante que propone un delicado desmerecer de las escarlatas ('telas de color carmesí menos fuerte que el púrpura', Aut.) acompañado por un contrastivo quiebro final humorístico en que se conjugan los términos cochinilla ('insecto de origen mejicano del que se extrae un colorante sucedáneo de la púrpura') y puerca ('hembra del cerdo, también llamado cochino). Sinéresis obligada sobre purpúreas en el v. 53.

57-64. Las corrientes metáforas que identifican las preciosas perlas con los dientes y los finos corales con los labios apoyan la loa introductoria a la boca de Leucótoe, que sobrepuja en su belleza natural al más preciado mármol (rocas marpesias, por el monte Marpesus de la isla de Paros, famoso por sus blancos mármoles estatuarios) enriquecido de los corales de Tinacria (la antigua Sicilia apreciada también por su riqueza mineral) o las perlas de la opulenta ciudad persa de Ormuz. Respecto al adjetivo indiana, $A u t$. reconoce ser referido a las Indias y no a la India, si bien el término se usaba para aludir el ámbito oriental [cf. Góngora aplicado a la mano de Clori («indiano marfil») en el soneto de 1620 De una dama que, quitándose una sortija, se picó con un alfiler o al océano Pacífico («mar Indiano») en su Fábula de Hero y Leandro «Aunque entiendo poco griego»].

La siguiente cuarteta apela a locuciones hechas como en mi conciencia («especie de aseveración que muchos tienen por juramento..., Aut.) o por la barba ('con descaro', cf. Aut. 1770, s. v. barba, mentir por la) para enfatizar una insultante belleza que deja desmentida (en su acepción «vencer o exceder compitiendo en alguna acción o perfección, hacer verdad en sí lo que o fabulosamente o por ponderación se atribuye a alguna cosa o sujeto», Aut.) a la hermosura más febea, esto es, a la más 'perfecta, ideal' o 'apolínea', ya que es el calificativo que se deriva de Febo Apolo. Con la primera de las locuciones se introduce una intromisión del narrador que pretende dar realce y veracidad a su artificiosa construcción; la segunda procura un evidente juego entre barba y febea, ya que el nombre de Febo aplicado a Apolo se justifica no sólo por su identidad con el sol sino también en su calidad de efebo imberbe: «[...] Item Apolo dizian phebo quasi ephebo sin barba que es nueuo moço» (Alfonso de Palencia, Universal vocabulario en latín y en romance [Sevilla, 1490], ed. facs., Madrid, Comisión Permanente de la Asociación de Academias de la Lengua Española, 1967).

65-68. Movimiento y tersura distinguen el cuello de la muchacha - y en ello lo deshonra, apartándose igualmente de su frialdad - del mármol de Caristos, isla griega de Las Cícladas especialmente destacada por sus mármoles, con quienes comparte sin embargo su blancura (de nieve) y una figurada resistencia (columna) para sustentar en síntesis hiperbólica todo el cielo descrito previamente. Nótese el gusto en esta secuencia por emplear como artificio lingüístico verbos en negativo (desmentir, deshonrar) para significados positivos.

69-72. La anafórica perífrasis eufemística para aludir al pecho de Leucótoe da paso a un díptico en paralelo en que los adverbios todo y nada y la oposición topográfica Sierra nevada y Sierra morena concentran en su antítesis el efecto de la ponderación. Descartar la mayúscula inicial que propone el impreso provocaría simplemente el contraste blanco-moreno para destacar albura en la piel de Leucótoe. Pero la lectura en mayúscula que propongo incidiría además en el volumen de sus senos ya que en Sierra Nevada se reconocen altas cumbres frente a la reconocida llaneza de Sierra Morena.

73-76. La llamativa cintura de Leucótoe acumula en su estrechez un amplio y significativo abanico de recursos burlescos. Su aniquiladora delgadez se diversifica entre la comparación de superioridad con la figura del barbero, en quien recaen sátiras y burlas áureas primordialmente en su calidad de hacedor de sangrías, y la comparación de igualdad con el puñal buido («lo así acicalado y hecho punta, que con particularidad y común uso se dice del puñal de tres esquinas», Aut.). Por otra parte, su extrema flaqueza (sentido metafórico de buido) se refuerza con el chiste en calambur sin bacías (en referencia a las vasijas de barbero, 'que no tiene aunque se le asemeje') ni ballenas («ajustador que traen las mujeres, que por otro nombre se llama cotilla», Aut., 'y que no necesita al estar delgada'). El verso final de la secuencia alberga sin duda la ironía que ofrece el sentido figurado de empuñar ('lograr' , 'conseguir'), en consonancia con las provocaciones de la muchacha descritas hasta el momento.

77-80. La sublime blancura de sus manos, unible (arrimarse) a la de jazmines y azucenas, se opone ya de manera explícita en esta cuarteta a la falta de candidez y pureza que destilan sus provocativos dedos (diez mandamientos: «en estilo bajo llaman así los dedos de las manos cuando se usa de ellos para comer o para castigar», Aut.). El efecto deviene aquí de nuevo del contraste entre símiles poéticos recurrentes y la traición al acudir al estilo bajo y a la privación de la azucena de su simbolismo más establecido en torno a un término puramente latino candor.

81-84. Con el fetichismo erótico del pie femenino de fondo combinado con el tópico elegíaco de las insignificantes cenizas que encierran grandes urnas (véase E. Camacho Guizado, La elegía funeral en la poesía española, Madrid, Gredos, 1969, p. ) se burla en estos versos la amplitud del zapato (urna espaciosa) 


\section{Belén Molina Huete}

que 'defiende' el pequeño pie de Leucótoe. El impreso lee Una espaciosa al pie breve/ hizo pulida defensa, pero considero que tanto el sentido como la lógica sintáctica justifican la corrección que propongo. Sobre el afán de pintar pequeño el pie de la dama versa el chiste de la Fábula burlesca de Hero y Leandro de García Medrano (1631): «que hay poetas ladrones indiscretos / de pies de damas, como de concetos: / que juzgando que en esto las festejan / por glosillas los pies, cojas las dejan» (José $\mathrm{M}^{\mathrm{a}}$ de Cossío, Fábulas mitológicas en España, Madrid, Espasa-Calpe, 1952, p. 693). Nuevamente hay lugar al contraste entre términos cultos y vulgares y una reunión coincidente a través de imágenes degradantes próximas. Así, la ennoblecedora metonimia que avala referir el pie como coturno se matiza con el vulgar de polvillo que, al margen de la conexión con el dibujo funerario parodiado, extrema su pequeñez y lo devalúa al asimilarse a los guantes de polvillo (según Covarrubias, guantes olorosos; y de poca altura dentro de la distinción según revelan expresiones como más baladí que guante de polvillo o el hecho de servir de baja condecoración en justas poéticas); y se corresponde después con un explícito zapato al modo de tabaquera ('caja para sorber el tabaco', molido, claro está). La imagen remite, pues, a una deformación burlesca de la más que apetitosa acción de besar el pie de la dama (recordemos «el coturno besar dorado intenta» de la gongorina Fábula de Polifemo y Galatea). Por otra parte, además, habría que tener en cuenta que la circunstancia de calzar ancho y holgado (urna espaciosa) podría relacionarse con la acepción de Aut. que reza: «Además del sentido recto de ponerse los zapatos anchos, metafóricamente es tener la conciencia relajada, y vivir licenciosamente y a sus anchuras», muy en correspondencia a la falta de candidez antes expresada.

85-88. Las dos trayectorias sobre las que ha ido versando el retrato de Leucótoe quedan finalmente sintetizadas y resueltas de manera explícita en la aposición que ocupa esta cuarteta: es mujer hermosa y buena pero a la vez de seductoras costumbres, concretadas en ese desgarro sobrado ('arrojo, descaro', o también 'movimiento airoso y agraciado de los ojos de las dama') semejante al usado por la venus («por lisonja o ponderación de su belleza a la mujer especialmente hermosa aludiendo a la deidad», Aut.) más libre o suelta (soltera). Nótese como el referente mítico se degrada en el empleo de la antonomasia matizada en lo descocado y además por la ambivalencia del término ninfa, 'deidad' o 'moza que se precia de dama' (Aut.) en su sentido recto, pero 'prostituta' en su sentido marginal. Asimismo la evocación erótica queda servida con el empleo del término desgarro, 'desvergüenza' pero también 'rompimiento' (acaso himenal).

89-96. La recolectio anterior da paso a un nuevo período narrativo que se alarga hasta el v. 132 y que sirve para avanzar en la historia ovidiana. A modo de silepsis (rendido Apolo) se adelanta el enamoramiento del dios como artimaña de Cupido (el chipriota - por extensión del origen atribuido a Venus - ciego; cf. el v. 98 de la Fábula de Europa de Pantaleón también con diéresis estilística), que con su flecha de amor (la dorada, después prevenido arpón) venga a su madre Venus (la ofendida Citerea del v. 112, cuya infidelidad con Marte ante Vulcano fue delatada por Apolo, acusación venérea, pues, doblemente) de la misma manera que la flecha que provocó su persecución a Dafne fue fruto del resarcimiento de Cupido por haberse burlado Apolo de su uso del arco. Curiosamente, P. Dioscórides (Acerca de la materia medicinal y de los venenos mortíferos, ed. Andrés de Laguna [1554], Madrid, Ediciones de Arte y Bibliofilia, 1983, I, cap. LXIX) expresa la semejanza en naturaleza sagrada entre el árbol del incienso (en que se convertirá Leucótoe) y el del laurel (en que se transformó Dafne). Exigida la sinéresis en venérea.

97-104. La dorada flecha, el prevenido arpón se transforman ya en un ardiente estímulo que impele inmediatamente al dios a intentar alcanzar la dama virgen haciendo de ello, cual relata Ovidio de manera más extensa, su única razón de ser. Así se entiende sincréticamente que es Leucótoe Aurora más bella que cada mañana persigue Apolo al hacer nacer el día en tanto que sol al que da paso el carro de la Aurora (omite Matos en esta ocasión la intencionada reflexión de Ovidio en torno a las dejaciones de Apolo en sus deberes tras el enamoramiento y la mención a las otras amantes que abandona; advertir cómo no interesa por omisión de continuación de la historia). Con todo, los cuidados de su padre Órcamo le impiden alcanzarla. El epíteto agíleo o agieo - con necesaria sinéresis aquí - se aplica a Apolo como 'dios que preside las calles' (cf. Epithetorum de Ravisio Textor [1518] o el Dictionarium historicum, geographicum, poeticum de C. Stephanus [1606]: «Agyleus, sive, ut habet Macrobius, agyeus, Apollo dictus est ab Atheniensibus, quod ei in viis publicis suae urbis ex resposo statutis altaribus sacrificarent. Agu $€^{a j}$ enim illi vias dicut... Horat. Lib. IV, Carm. Ode 6»).

105-120. Siendo el camino infranqueable a la vez que inexorable su afición, y siguiendo el discurso ovidiano aunque omitiendo el detalle de estar hilando, Apolo decide acceder a la muchacha bajo el disfraz de la bella Eurímone (Eurimona), su madre, y consigue quedarse a solas con Leucótoe. Se acude en el fragmento a varios recursos ingeniosos. Por una parte, la actualización que supone la 
alusión a la complicidad para favorecer a los amoríos de las dueñas («señora viuda de respeto que en los palacios y casas nobles guardaba las antesalas y tenía autoridad sobre el resto de criadas», Covarrubias). Sobre la vigilancia férrea en los palacios habla Baltasar de Vitoria en su Teatro de los dioses de la gentilidad (Madrid, Imprenta Real, 1676, pp. 603-606: «con quien se tienen tanto recato por haber en los palacios tantos Argos que divisen los menudos átomos de descuidos; pero eso tiene el amor, que facilita los mayores imposibles y halla caminos abiertos en las mayores dificultades». De otro lado, terciar la doble a una puerta es juego de palabras (terció-doble) para indicar que cerró ('atravesó', terció) la puerta de la sala con 'llave' doble: «La que ordinariamente se hace para las casas principales, la cual, además de las guardas regulares, tiene unos dientecillos que alcanzan a dar segunda vuelta al pestillo, y entonces no se puede abrir con la llave sencilla», Aut.). Citerea es el nombre griego de Venus por el templo que le fue consagrado en Citera, isla meridional del Peloponeso en cuyas aguas nació según algunas tradiciones.

121-132. Leucótoe, que piensa no haber peligro ante su propia madre (falsa majestad porque es Apolo, antes fingida reina) aunque permanece atenta ('prevenida') ante la temerosa acción de encerrarse a solas con ella, recatada (humilde) muestra sus respetos cuando Apolo (el lecucadio, por Léucode, isla jónica donde era adorado) se desprende del disfraz. La brevedad del momento relatado por Matos resulta claramente a propósito a partir del retraso que Ovidio procura en la vuelta de Apolo a su forma original, pues en las Metamorfosis las palabras del dios se pronuncian bajo la forma de Eurímone. La prolija cautela (recordemos el cauto previo en el v. 113) parece ya afectar también a los efectos conceptistas del poema, de manera que el autor se dispone a romper con la mesura expresiva y dar paso de nuevo a la cascada de ocurrencias que caracterizan el canto polifémico, como nuevo excursus amplificativo sobre el modelo ovidiano reducido a vanagloriar sus potenciales como ojo del mundo y manifestar su deseo de la doncella, que se desarrolla entre los versos 133-216 y al que se da pie con el hiperbólico sentir que denota el v. 132.

133-136. Resulta tópico en el discurso de auto-halago para atraerse la voluntad de la amada acudir en primer lugar a una noble genealogía: Apolo es hijo de Júpiter, conocido como Elicio remitiendo a su naturaleza eléctrica de rayo y trueno que la tierra atrae («Elicius: Iouis cognomentum, qui in Aventino colebantur, ab eficiendis, hoc est, evocandis fulminibus impositum», Stephanus). Su poderío celeste y universal se ejemplifica con la imagen sobresaliente del dios que, rector caeli, sobre las grandes montañas de Tesalia (Olimpo/Olimpio y Osa) ve a sus pies caídos a los gigantes que contra él se revelaron superponiendo ambas (Gigantomaquia). Ante la lectura del original, Olmpio, cabría entender errata bien por omisión - Ol[i/y]mpio - bien por trastoque de tipo - Olimpo - , ya que de las dos formas puede documentarse. He optado por la segunda por ser la más común.

137-156. Sigue ahora la serie de hazañas que se atribuye: Apolo venció a los pocos días de nacer a la serpiente Pitón, devastadora bestia de Delfos, y a la que Juno había encargado impedir el parto de Leto, madre del joven dios, celosa de su unión con Júpiter (vv. 137-140; el original escribe Fitón en corriente ultracorrección cultista Phiton < Pithium < Пu் $\omega \omega$ ). Los vv. 141-144 aluden a la tradición de Apolo pastor a la que llega por el castigo recibido por Júpiter tras haber matado a los cíclopes que fabricaban los rayos del gran dios, el cual había matado al hijo de Apolo Asclepio por ser capaz de resucitar. Así, hubo de servir a un mortal como esclavo durante un año: al rey Admeto de Feras, en Tesalia, del cual fue boyero. Gracias a Apolo, las vacas (vitelas) tenían siempre parto doble y llegó la prosperidad al reino. El crujido (metonimia por el látigo para llevar el ganado) acaso sea calificado de balear por la fama de los honderos pastores de las islas Baleares. Ticio fue un gigante hijo de Júpiter - de ahí mi hermano-, a quien Juno también encomendó su venganza sobre Leto. Matos funde en estos versos 145-148 dos tradiciones (segundo castigo): la que hacía responsable de la muerte de Ticio a Apolo y su hermana y la que explica que fue Júpiter el fulminador y al bajar a los infiernos dos águilas devoraban su hígado que renacía con las fases lunares; otros autores (Tibulo, I 3, 75) narran como castigo que el cuerpo del gigante quedó extendido sobre nueve hectáreas de tierra [por error, el original impreso lee entreñas al v. 146]. Flegias fue padre de Coronis o Corónide, seducida por Apolo y madre de Asclepio; la ninfa le fue infiel y el dios la mató, a lo que Flegias respondió pretendiendo incendiar el templo de Delfos. Virgilio (Eneida, VI, 618ss) lo sitúa en los infiernos (orco) castigado por su atrevimiento; allí sufre bajo una gran piedra amenazado de ruina, siempre temeroso de desgracias (vv. 149-152). La siguiente cuarteta (vv. 153-156) parece referirse a Marsias, sátiro hijo de Olimpo, que retó a Apolo afirmando ser mejor músico en su flauta que el dios en la lira. Venció Apolo y como escarmiento, tras colgarlo de un pino, lo desolló. El culmen de sus arrogantes proezas acaba siendo - en claro quiebro humorístico tras la enumeración mítica - su potestad si se le obliga para condenar al hombre al sopor y a dolores de cabeza por sobreabundancia de calor. Para las referencias míticas de este pasaje, cf. P. Grimmal, Diccionario de Mitología griega y romana, Barcelona, Paidós, 1991. 


\section{Belén Molina Huete}

161-164. El último tramo del parlamento de Apolo tiene como preámbulo un descenso que muestra su postración, aun siendo tan poderoso, a la belleza de Leucótoe por causa de amor, que todo lo vence (omnia vincit amor, incluso a los dioses). La cuarteta que articula el nuevo paso a las ofrendas que se dispone a dispensar el joven enamorado y los beneficios que la doncella gozará si concede a sus requiebros (vv. 165-216) presenta un paralelismo en rima final (me rinde/me eleva) que encierra la paradoja petrarquista apoyada en los tópicos de beldad y mirada-ojos y que también habría que interpretar en sentido erótico dado el tono que en adelante in crescendo irá contagiando al poema.

165-176. Lo primero que entregará a Leucótoe será su luz y todo cuanto ella gobierna. Adviértase la antítesis del término humilde al inicio con el discurso precedente, reorientando el acento hacia un cortejo más sensual y condescendiente con los gustos de la dama. No se abandona, sin embargo, la ostentación del dios, que promete hacer señora a Leucótoe de cuanto gracias al sol vive (vv. 165-168), que le concede las estrellas como alfombra (rodapiés o carpeta) del orbe (vv. 169-172) y hasta la luz de la propia luna-Diana, hermana gemela de Apolo, ayudante de su madre Leto para darle a luz a él, y triforme en su triple vertiente de Diana-Artemisa, Selene y Hécate en tanto que luna en el día, luna en la noche y luna del inframundo (vv. 173-176). Siendo la luz el elemento protagonista de esta serie se justifica la abundancia de léxico denotativo en este sentido; no obstante, no debe perderse de vista el valor connotativo sexual que impregna muchos de los términos (mi fuego imperante engendra, nocturnas centellas por 'semen'). Nótese el valor causal de que 'por la que' (v. 168).

177-188. A continuación cederá Apolo su puesto de dios, encumbrando a Leucótoe a la divinidad. En primer lugar haciéndola receptora de las ofrendas preciosas que como dios recibe tanto en los lugares griegos como Tebas - cuyo templo más famoso fue el dedicado a Apolo Ismenio-, como en los de oriente próximo: Fenicia, de donde le llegaban virtuosas esclavas para su culto en Delfos; Pancaya, región de la llamada Arabia Feliz, cantada por los poetas por su abundancia de incienso, mirra y otros perfumes; o Licia, ciudad de Asia Menor limítrofe al sur con Frigia cuyos habitantes adoraban a Apolo (vv. 177-180). Después, haciéndola destinataria del ámbar en que se transforman las lágrimas de las helíades (Héliadas para evitar hipermetría), hermanas de Faetón, que convertidas en álamos lloran su muerte cuando, atacado por un rayo de Júpiter, se precipitó a las aguas del río Erídano (vv. 181-184); algunas teorías hacen del ámbar el posible origen de la ambrosía mítica que otorgaba la inmortalidad a los dioses. La secuencia se completa (vv. 185-188) con su elevación a una sacralidad reconocida; y todo a cambio de aliviar una amorosa dolencia, que más allá del tópico sufrir de amor, se identifica en sentido erótico con la desazón provocada por el deseo.

189-204. En paralelo procedimiento, que intensifica con una estrofa más, se enumeran ahora a través de perífrasis mitológicas la aves que en calidad de ricos manjares Apolo serviría en bandeja a Leucótoe. El obsequio de un pájaro vivo a la dama fue costumbre clásica - con más o menos evocaciones eróticas - que queda aquí caricaturizada y transformada en un tema de los propiamente carnavalescos en la poesía jocosa, donde alimentación y sexo, gula y lascivia, están normalmente conjugados.

El cisne (vv. 189-192) es ave consagrada a Apolo que sobrevoló la isla de Delos al nacer y que ocupa los tiradores del carro que Júpiter le envió como regalo. Ha sido empleado hasta la saciedad por los poetas la alusión a su dulce canto previo a la muerte; la calificación escarmentado parece remitir a la versión del mito que hace a Cicno hijo de Apolo y Tiria, hermoso pero a la vez caprichoso y áspero hasta hacer desesperar a sus más apegados, como Filio que lo amó intensamente hasta desistir debido a las continuas pruebas a que Cicno lo sometía; solo al fin, Cicno decidió suicidarse tirándose a un lago junto a su madre y Apolo los compadeció transformando a ambos en cisnes. Su dulce canto se alía precisamente por la proximidad a Apolo. Los vv. 193-196 recuerdan el ave fénix, oriunda de Arabia y relacionada con el sol en Egipto, que cuando llega el fin de su larga vida, acomoda un nido con plantas aromáticas. De aquí parten entonces dos tradiciones sobre su regeneración: 1) Extiende las alas al sol, que las prende y de sus cenizas resulta un gusano blanco que da origen a una nueva criatura. 2) Impregna o unta (lardea) su cuerpo con su propio semen (aquí acaso eufemísticamente denominado sangre, como era corriente con sentido erótico). El pavo real (vv. 197-200) es el animal que acoge en su hermosísima cola desplegada los múltiples ojos (bella impresión, lumbre ciega) del forzudo Argos que vigilaba la vaca Io, amante de Júpiter, por encargo de Juno; Mercurio consiguió matarlo y la diosa, en premio a su sirviente, trasladó sus ojos al ave que le estaba consagrada y que tiraban de su carreta (tirantes). Los pavos reales eran considerados manjar sabroso.

Como queda apuntado, no puede obviarse en todo el pasaje la tentación a identificar los pájaros relatados - bellos, que renacen de su propio semen, que se despliegan en seducción - con el órgano sexual masculino ni tampoco dar una interpretación plenamente erótica a la última de las cuartetas (vv. 201-204). La repetición irónicamente intencionada en todas, si todas de agradan, la mención a la 
manera de ser cocinadas -'soasadas' (perdigadas) o rellenas - y el refrendo de la gula - ligada a la lascivia en la poesía jocosa - condicionan la segunda lectura.

205-208. Con la doble invitación quiasmático-reiterativa al goce del momento (Aprovecha tu hermosura / mis cuidados aprovecha) se produce una nueva transición hacia una mayor opulencia (imposibles finezas) y ya, sin lugar a dudas, a un más acentuado goce sexual.

209-216. Queda claro que lo pretendido es yacer con la virgen Leucótoe. La recompensa avanza hacia preciadas joyas y paseos en coche, sin duda premios preciados por las mujeres. Pero el traslado a lo erótico es ya inexcusable. Los profundos y duros diamantes se asocian comúnmente con las 'gotas seminales'. Es erotema acuñado rueda 'cunnus', así como lo acerado es 'lo que tiene acero o está mezclado con él' y «acero» se vincula por sinécdoque a «espada» y ésta a 'pennis'. Por otro lado, el coche pertenece al contexto cortesano y contribuye a la visión degradante de sus damas, fácilmente deslumbrables (nótese luciente, rutilante) con tal dádiva. Se trata de una anacronía burlesca donde se pone en chanza el ansia de las mujeres por viajar en coche y por comprar, especialmente joyas. Así, la identificación de la Vía Láctea celeste por donde circula Apolo con la calle mayor y las covachuelas ('tiendas pequeñas que ocupaban los sótanos bajo el nivel de calle'). En el caso del Madrid del XVII [1625], se documenta que el gremio de joyeros se situaba primordialmente en la calle Mayor, la de Atocha, Santa Cruz, Postas y las covachuelas de San Francisco (véase J. Espinosa et al., «La feudalización de la sociedad madrileña en el siglo XVII», en V. Pinto Crespo y S. Madrazo Madrazo (dirs.), Madrid. Atlas Histórico de la ciudad (siglos IX-XIX), Lunwerg Editores, Madrid, 1995, pp. 182-193, leyenda Plano 81). Desde el punto de vista literario, fueron comunes las imágenes burlescas al respecto. J. Polo de Medina, en su Fábula burlesca de Apolo y Dafne (a. q. 1655), concluye el reclamo de Apolo: "mira que soy hermoso y tengo coche". / Coche le dijo apenas, / cuando, corriendo como Dafne iba, / volvió la cara, un poco compasiva, / y dijo sin pararse: / "Pues no me paro a coche, no hay cansarse; / un imposible labra, / atrás no ha de volverse mi palabra, / y ha de cumplirse, si una vez lo dije, / aunque aquesto del coche es quien me aflige"»; J. Jerónimo Serra, en un soneto de la Primera parte de las Flores de poetas ilustres de España ordenada por Pedro Espinosa (1605) acusa al joven dios de haber sido tierno con Dafne y no haberla por ello conseguido en los siguientes términos: «Por dios, que a ser su pecho fuerte acero, / pudiera con sus minas ablandarla / y más dándole el coche algunos días». También Salas Barbadillo, en un texto sobre Apolo y Dafne refiere: «iQué desdichado fue Apolo / en no amar en estos tiempos / bajara en su coche al prado / y en fe de él le hablara luego» (cf. T. W. Keeble, «Some mythologycal figures in golden age satire and burlesque», Bulletin of Spanish Studies, 25, 100, 1948, pp. 238-246, esp. 238-241).

217-224. Un brevísimo desenlace sirve de conclusión al poema, en consonancia con la inmediata respuesta de Leucótoe y en contraste con el pesaroso discurso previo. Leucótoe, de nuevo bajo la advocación procaz de ninfa, accede al eufemístico nupcial ensayo haciendo honor a su nombre - etimológicamente 'la blanca y rápida' - y con intensa aprobación, indicada en el pleonasmo permisivas licencias; lejana, pues, de la Leucótoe ovidiana, atónita y temerosa que deslumbrada por el dios al desproveerse del disfraz no puede más que acceder a su deseo y lejos también de la intención del autor provocar cualquier debate en torno a la voluntariedad o no con que la princesa concede. Lo elegante, o el gesto esperado, sería el de tomar de la mano a la joven para ir al lecho. Sin embargo, la alusión en disyuntiva sinonímica a la pierna da idea de la violencia o prisa del dios, incidiendo en la imagen más lasciva del momento en contraposición a la ternura erótica con que el motivo aparece en otros textos clásicos (cf. el epilio de Reposiano [s. III] titulado El concúbito de Marte y Venus: «La diestra de Marte acariciaba el seno de la Pafia / y colocando su izquierda bajo su cuello, para no herirla con el peso, / la recuesta sobre guirnaldas de blancos lirios y rosas. / Con la suave caricia de su pierna, una y otra vez / avivó unas llamas que la propia diosa alimentaba»; trad. de J. Ponce Cárdenas en Evaporar contempla un fuego helado. Género, enunciación lírica y erotismo en una canción gongorina, Analecta Malacitana, Málaga, 2006, p. 212). Las representaciones pictóricas del mito se centran todas en esta escena en que Apolo y Leucótoe acceden al tálamo; tomándola de una pierna sólo puede verse en el aguafuerte de Antonio Tempesta (1555-1630) dentro de la serie de las Metamorfosis de Ovidio titulada Leucothoe a Phoebo vim patitur que se conserva en el Museo de Bellas Artes de San Francisco (California):

http:/ / search3.famsf.org:8080/view.shtml?keywords=\%6C $\% 65 \% 75 \% 63 \% 6 \mathrm{~F} \% 74 \% 68 \% 6 \mathrm{~F} \% 65 \&$ artis $\mathrm{t}=$ \& country $=$ \&period $=$ \&sort $=$ \&start $=1$ \&position $=2 \&$ record $=58226$

La acepción salaz de lograr 'poseer sexualmente' en aspecto imperfectivo durativo nos adentra en la transformación más nueva 'la que sucede por primera vez', esto es, la pérdida de virginidad de Leucótoe, del mismo modo que Sánchez de Viana recuerda y sintetiza en su traducción en verso de las $M e-$ tamorfosis (1589): «desde entonces dejó de ser doncella». Éste es sin duda el mayor efecto del poema: 


\section{Belén Molina Huete}

sustituir el protagonismo de la transformación ovidiana de Leucótoe en incienso tras ser enterrada viva por su padre para condenar su ligereza por esta otra e interrumpir aquí la fábula como si su sentido no fuera otro que éste, dando lugar así no sólo a una burla del código genérico-fábula mitológica sino también a una burla del paradigma. 